\title{
Efficacy of Botanical Fungicides against Curvularia lunata at Molecular Levels
}

\author{
Abdel Ghany TM ${ }^{1,2 *}$, Abdel-Rahman M. Shater ${ }^{2,4}$, Moustafa E. Negm ${ }^{3}$, Mohamed A. Al Abboud ${ }^{2}$ and Nadeem I. Elhussieny $^{2}$ \\ ${ }^{1}$ Botany and Microbiology Department, Faculty of Science, 11884, AL-Azhar University, Cairo, Egypt \\ ${ }^{2}$ Biology Department, Faculty of Science, Jazan University, 114, KSA \\ ${ }^{3}$ AL Ghad International Colleges for Applied Medical Science, Riyadh 2174, KSA \\ ${ }^{4}$ Biology Department, Faculty of Science and Technology, Thamar University, Yemen
}

\begin{abstract}
Juniperus procera and Avicennia marina extracts were tested for their antifungal activity against Curvularia lunata isolated from rice (Oryza sativa L.). Eextracts were able to supress C. lunata at high concentration $3 \mathrm{mg} / \mathrm{ml}$. $J$ procera extract retarted the growth C. lunata by $88.42 \%$ while $A$. marina extract was less effective (37.50\%). Nucleic acids content of $C$. lunata was reduced by both plant extracts especially $J$. procera extract in a distinct reverse proportion relationship when compared with the untreated samples. The antifungal effect of $J$. procera and $A$. marina extracts were explored at the molecular level, using random amplification of polymorphic DNA (RAPD). The results demonstrated polymorphic banding pattern. Secondary metabolites analysis of $C$. Iunata revealed that both plants extracts were capable of blocking biosynthesis of some secondary metabolites including curvulalic acid and lunatin.
\end{abstract}

Keywords: Efficacy; Botanical fungicides; suppression; Curvularia lunata; Molecular levels

\section{Introduction}

About 738 million metric tons rice are produced annually [1], therefore Gautam et al. [2] suggests that it is necessary to check the rice grains before allowing distribution for public use. Different fungi are significant destroyers of seeds during storage and crops at seedling stage. They are also remain dormant in seed and transmit to seedlings and mature plant showing different symptoms [3]. Fungi including, Curvularia oryzae, and C. lunata, have been isolated from seeds of different varieties of rice [4-6]. Curvularia phytopathogenic species produce spots in grains and seeds, as well as damage to plant leaves, their species are saprophytes, occur mostly in tropical and subtropical areas, and are isolated from soil, air, organic matter, plants and animals, including humans [7]. This genus of filamentous fungi colonizes soil and vegetation and spreads by airborne spores. Some of the 40 Curvularia species are phytopathogens. Plant diseases range from seedling failure to leaf blight, [8]. Curvularial growth on stored grain, thatch, and other dead plant material looks like smudges of blackish dust. Culture filtrate of Curvularia lunata caused reduction in seed germination, radicle, plumule length and low vigour index of Trigonella foenumgraecum [9].

It is now realized that chemical fungicides cause serious environmental problems and are toxic to non-target organisms [10-13]. The toxic effect of synthetic chemicals can be overcome, only by persistent search for new and safer pesticides accompanied by wide use of pest control methods, which are eco-friendly and effective. Plant metabolities and plant based pesticides appear to be one of the better alternatives as they known to have minimal environmental impact and danger to consumers in contrast to the synthetic pesticides $[14,15]$. Rahman [16] observed that bishkatali, garlic, ginger and neem extract were effective against seed-borne Curvularia lunata. Garlic extract was superior in terms of reducing seed-borne infections by A1ternaria spp., Bipolaris sorokiniana, Curvularia lunata, Fusarium spp. of wheat to other extracts followed by ginger and neem $[17,18]$. Methanolic extracts of Bridelia montana and Scoparia dulcis showed the high antifungal activity against $C$. lunata and recorded minimum inhibitory concentration below $50 \mathrm{mg} / \mathrm{ml}$. The overall reports provide promising baseline information for the potential use of the crude extracts from medicinal plants in the treatment of fungal diseases caused by Curvularia lunata [19]. The efficacy of leaf extracts of Gliricidia sepium, Tithonia diversifolia, Phyllanthus amarus and Morinda lucida were assessed in vitro [20] to control C. lunata. The extracts of the four plants suppressed the growth of $C$. lunata in vitro. Mangroves are medicinal plants and extracts from different parts of them are widely used through the world. These are considered as rich sources of steroids, triterpenes, saponins, tannins, alkaloids and flavonoids. Antiviral, antibacterial and antifungal activity of the extracts from these plants have been shown in former studies [21,22]. A. marina and A. officinalis were used as test plants due to the presence of much evidence that prove their therapeutic value against microbial infections [23]. Also preliminary studies have been demonstrated that the mangrove plant extracts have antibacterial activity against pathogenic bacterial strains; Staphylococcus sp., E. coli and Pseudomonas sp. [24]. Juniperus species have been extensively investigated as a source of natural products with potential antibacterial, antifungal and insecticidal activities [25-27]. Mariana and Camelia, [28] reported that Juniper oil has inhibition action against Aspergillus niger, Fusarium oxysporum, Monascus purpureus and Penicillium hirsutum. The aim of this study was to determine antifungal activity J. procera and A. marina extracts as safe alternative for controlling C. lunata and their mechanisms on molecular levels.

\section{Material and Methods}

\section{Isolation and identification}

Stored grains of rice (Oryza sativa L.) were surface sterilized

*Corresponding author: Tarek Mohamed Abdel Ghany, Botany and Microbiology Department, Faculty of Science, 11884, AL-Azhar University, Cairo, Egypt, Tel: 0222633070; E-mail: tabdelghany@yahoo.com

Received July 01, 2015; Accepted July 09, 2015; Published July 12, 2015

Citation: Abdel Ghany TM, Shater ARM, Negm ME, Al Abboud MA, Elhussieny $\mathrm{NI}$ (2015) Efficacy of Botanical Fungicides against Curvularia lunata at Molecular Levels. J Plant Pathol Microb 6: 289. doi:10.4172/2157-7471.1000289

Copyright: ㄷ 2015 Abdel Ghany TM, et al. This is an open-access article distributed under the terms of the Creative Commons Attribution License, which permits unrestricted use, distribution, and reproduction in any medium, provided the original author and source are credited. 
with $0.1 \%$ mercuric chloride for two minutes followed by washings with sterilized water. The surface sterilized grains were transferred on three layered filter paper beds in $9 \mathrm{~cm}$ diameter sterilized Petri plates containing Czapek-Dos growth medium. The growing fungus was identified according to the cultural characteristics and spore morphology [29] as Curvularia lunata.

\section{Treatments}

Juniperus procera and Avicennia marina leaves were collected from Jazan region, KSA. Freash leaves $(500 \mathrm{~g})$ of plants were air-dried at room temperature, ground into powder using an electric grinder, then extracted with methanol in a Soxhlet. The solvent was removed using rotary evaporator under reduced pressure at temperature below $50^{\circ} \mathrm{C}$. The resulting crude extracts were stored at $4^{\circ} \mathrm{C}$ in dark until used. Carbomar (Methyl Benzimacold-2-ylcarbamate) from (Gyangsoetrnal, China) was used as chemical fungicide.

\section{Anti-fungal assay}

Poisoned food technique was used. Potato dextrose agar medium (PDA) suplemented with different concentrations of each palnt extract and carbomar were prepared separately. About $25 \mathrm{ml}$ of the growth medium was poured into each petri-dish and allowed to solidify. Five $\mathrm{mm}$ disc of 5-day-old culture of the Curvularia lunata was placed at the center of the petridish and incubated at $27^{\circ} \mathrm{C}$ for 7 days, the growth was measured in millimeter. For each treatment three replicates were maintained. PDA medium without the methanolic extract served as control [30]. The toxicity eacg $\mid \mathrm{h}$ treatment in terms of inhibition percentage of mycelial growth was calculated by using the formula:

$$
\text { Inhibition }(\%)=\frac{\mathrm{Dc}-\mathrm{Dt}}{\mathrm{Dc}} \times 100
$$

Where Dc=average increase in mycelial growth in untreated samples, $\mathrm{Dt}=$ Average increase in the treated samples [31].

\section{Secondary metabolites detection}

After 10 days of incubation period, the growth medium ( PDA broth containing 1 and $2 \mathrm{mg} / \mathrm{ml}$ of J. procera and A. marina; 5 and $25 \mu \mathrm{g} /$ $\mathrm{ml}$ of Carbomar) of C. lunata containing extracellular metabolites was extracted twice with Chloroform/methanol $(2: 1 \mathrm{v} / \mathrm{v})$, then concentrated and separated using High-Performance Thin-Layer Chromatography (HPTLC) techniques. Twenty microliters of the samples, with or without treatment, were applied to HPTLC plates $(10 \mathrm{~cm} \times 10 \mathrm{~cm}$, $0.2 \mathrm{~mm}$ silica gel Merck 60 F 254 precoated plate; Merck Darmstadt, Germany) using CAMMAG LINOMAT 5 application system. The TLC plates were eluted for the detection of extracellular metabolites in toluene/ethyl-acetate/90\% formic acid 5:4:1 (TEF). Once the runs had finished, the plates were observed under visible and ultraviolet at 254 and $365 \mathrm{~nm}$ illumination. Griseofulvin dissolved in chloroform/ methanol 2:1 was used as standard in all cases and relative retention factor value ( $R f$ value) to griseofulvin were calculated as $R_{\mathrm{fg}}$. To identify the metabolites the absolute $R_{f}$ and the relative $R_{f}$ to griseofulvin $\left(R_{f g}\right)$ were measured. Secondary metabolites were identified by descriptions in literature and comparison with the available standard was made [3235]. Retention factor value ( $\mathrm{Rf}$ value): The distance that the spot of a particular compound moved up on the TLC plate relative to the distance moved by the solvent front is called the retention factor or Rf value. The Rf values of individual secondary metabolites were calculated by following, $\mathrm{Rf}=$ Distance traveled by the compound/Distance travelled by the solvent. Qualitative determination of secondary metabolites were done by comparing the $\mathrm{Rf}$ values calculated using CAMMAG TLC scanner at Regional Center for Mycology and Biotechnology (RCMB), Al-Azhar University Cairo, Egypt.

\section{RAPD analysis}

DNA from each treated and untreated C. lunata mycelia was extracted using DNeasy kit (Qiagen-Germany). PCR amplification was conducted using 5 random primers listed in Table 1 [36]. The amplification was performed in a thermal cycler programmed as follow: Cycle-1: $94^{\circ} \mathrm{C}$ for 10 minute, Cycle-2 : $97^{\circ} \mathrm{C}$ for 15 minute, $36^{\circ} \mathrm{C}$ for 1 minute, $72^{\circ} \mathrm{C}$ for 2 minute Repeat for 40 times, Cycle- 3 : $72^{\circ} \mathrm{C}$ for 10 minute and Cycle $-4: 4^{\circ} \mathrm{C}$ for 30 minute. PCR amplification products were separated by electrophoresis using $1.5 \%$ agarose gel and $100 \mathrm{bp}$ ladder. The products were visualized and photographed underUVtransilluminator.

The banding patterns of RAPD were scored using Gel analyzer 2010a software and data fed to the computer as 1 and 0 for the presence and absence of bands, respectively. Pair-wise comparisons of genotypes, based on the presence or absence of monomorphic and polymorphic fragments, were used to generate percentage of polymorphism.

\section{Results and Discussion}

Curvularia lunata was found associated with the contaminated seeds of rice (Oryza sativa L.). Under microscopic examination, Conidia were smooth-walled, olivaceous brown, end cells somewhat paler, conidia obovoidal to broadly clavate, curved at the subterminal cell, 25 $30 \times 10-14 \mu \mathrm{m}$.Conidiophores were erect, septate, unbranched, flexuose in the apical part, with flat, dark brown scars., 3-septate. Morphological characteristics of the isolated fungus were in agreement with Ellis, [29]. Earlier study analyzed 25 rice samples that were contaminated with one or more fungal genera like Aspergillus, Fusarium, Curvularia, Cladosporium and Alternaria [37]. Curvularia trifolii, C. lunata and C. brachyspora were isolated from 40 different paddy samples [38]. Isolated Curvularia lunata colonies showed morphological variation on the two used media (Czapek-Dox and potato dextrose agar media). C. lunata colony appeared light-brown to grey on Czapek-Dox medium while it turned to buff light when grown on PDA medium (Figure 1). The fungus failed to sporulate on PDA medium but heavy sporulation occurred on Czapek-Dox agar. The differences in media composition particularly, the carbon and nitrogen sources might be the cause of these phenomena. Lanisnik Rizner and Wheeler, [39] and Lanisnik Rizner and Romih, [40] observed that $C$. lunata was dark brown when grown in malt extract broth, however, it remained white or very pale brown when grown in yeast nitrogen base broth medium.

C. lunata was completely inhibited by $50 \mu \mathrm{g} / \mathrm{ml}$ of chemical fungicide Carbomar. Similar results were obtained by Shikha et al. [41] who used Carbendazim $(10 \mathrm{mg} / \mathrm{ml})$ to inhibit $C$. lunata growth. Topsin and mencozeb suppressed the growth of Curvularia sp. by $50 \%$ [42]. Even though effective and efficient control of seed borne pathogenic fungi can be achieved by the use of synthetic fungicides, they cannot be applied to grains because of their toxicity $[12,43]$. Thus, there is a need for safe, nontoxic, eco-friend and cheap alternative approaches to store

\begin{tabular}{|c|c|}
\hline Primer code & Nucleotide sequence $\mathbf{5} \mathbf{~} \mathbf{3}^{\mathbf{}^{\prime}}$ \\
\hline P1 & AGGAGGACCC \\
\hline P2 & ACGAGGGACT \\
\hline P14 & CCACAGCACG \\
\hline PE7 & AGATGCAGCC \\
\hline PE20 & AACGGTGACC \\
\hline \multicolumn{2}{|c|}{ Table 1: Ten-mer random primers. } \\
\hline
\end{tabular}




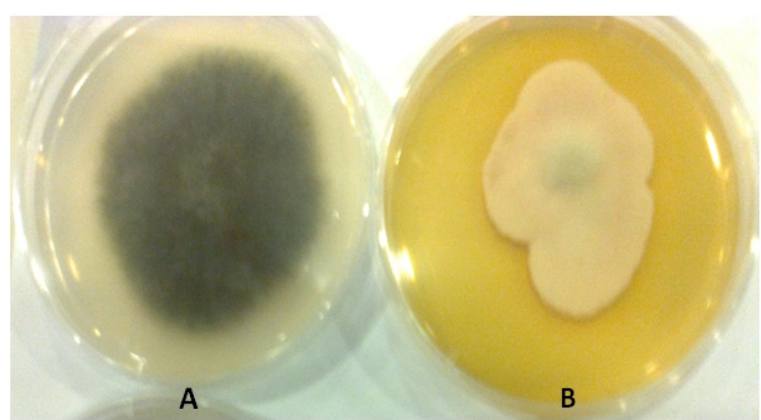

Figure 1: Growth of Curvularia lunata on PDA (A) and Czapek-Dos's (B) media.

grains/cereals for human consumption. Exploration of safe alternative antifungal agents, especially the plant extracts has intrinsic worth. Plant extracts as potential antifungal compound has been explored against several fungal species. In this study, two plants (J. procera and A. marina) extracts reduced C. lunata mycelium growth (Table 2). Although none of these plants extracts inhibited the mycelial growth $100 \%$, these plants have been reported to possess antifungal properties against $C$. lunata. J. procera extract was more effective against $C$. lunata than A. marina. C. lunata growth was inhibited by 88.42 and $37.50 \%$ when growth medium was treated with $J$. procera and $A$. marina extracts respectively. Recently, Abdelghany [27] reported the antifungal effect of $J$. procera crude extract against growth of Aspergillus flavus and Fusarium oxysporum. Surprisingly, A. marina extract at low concentrations induced the vegetative growth of C. lunata (Figure 2), but it suppressed the fungal sporogenisis. This may be due to A. marina extract component(s) reduced the activity of sporogenesis enzymes which saved energy for mycelial growth. Antifungal activity of $A$. marina was investigated Nayak et al., [44] who concluded that the leaf extract has both antifungal and antibacterial activities. Antifungal metabolites of A.marina include alkaloids, flavonoids and related compounds, fatty acids, oxygen heterocyclics, proanthocyanidins, quinones, stilbenes, terpenoids and triterpenoid, saponins [45].

Natural antifungal agents can be potential exploited in controlling the growth of fungi consequently inhibiting secondary metabolites production [46,47]. Therefore in recent years, much attention has been given to the preservation of grains by natural products so that the growth and mycotoxin production may be effectively retarded. Curvularia lunata secondary metabolites qualitative profile (Table 3 and Figure 3 ) indicates the ability of J. procera and A. marina extracts and carbomar to alter its metabolic pathways. Curvularia sp. secondary metabolites profile has been investigated by Trisuwan and his team [48], curvulapyrone, curvulalide and curvulalic acid, modiolides $\mathrm{A}$ and $\mathrm{B}$, pyrenolide $\mathrm{A}$, stagonolide $\mathrm{E}$, mycoepoxydiene, and deacetylmycoepoxydiene were identified. J. procera extract low concentration $(1.0 \mathrm{mg} / \mathrm{ml})$ was capable of blocking the biosynthesis of curvulapyrone and radicinin while higher concentration (2 $\mathrm{mg} / \mathrm{ml}$ ) blocked the synthesis of lunatin and curvulalic acid in addition to curvulapyrone and radicinin. Deacetylmycoepoxydiene, mycoepoxydiene, cytochalasin $\mathrm{B}$, radicinin and curvulapyrone were not synthesised by $C$. lunata in both media treated with low and high concentration of A. marina extract, while lunatin was not synthesised only in A. marina high concentration media. Except of cytoskyrins, all investigated metabolites were blocked by both carbomar concentrations. C. lunata produces cytochalasin B [49], that is a mycotoxins acts on the cytoskeleton and may show other bioactivities [50]. A. marina extract and carbomar inhibited cytochalasin B.

Al-Qurainy and Abdel-Megeed [51] stated that some antifungal agents have the capacity to alter the genetic material. This statement pushed this research to investigate nucleic acids content in both treated and untreated C. lunata samples (Table 4). Both plants extracts induced an increase in total DNA and RNA content of $C$. lunata especially at relatively low concentrations 1 and $2 \mathrm{mg} / \mathrm{ml}$ growth medium. On the other hand, it was found that DNA and RNA content decreased with the increase plant extracts specially with using J. procera. Carbomar sharply decreased the nucleic acids content of C.lunata compared with the control and plant extracts used.

Alternation in growth, sporulation, secondary metabolites pathways and nucleic acids content of $C$. lunata treated with $J$. procera extract, $A$. marina extract, and carbomar drive this study to investigate the potential genotoxic effects of the J. procera and A. marina extracts at molecular level using RAPD analysis. Two levels in the form of two different concentrations were tested for each extract against wild type (untreated sample). Carbomar treated samples were the positive

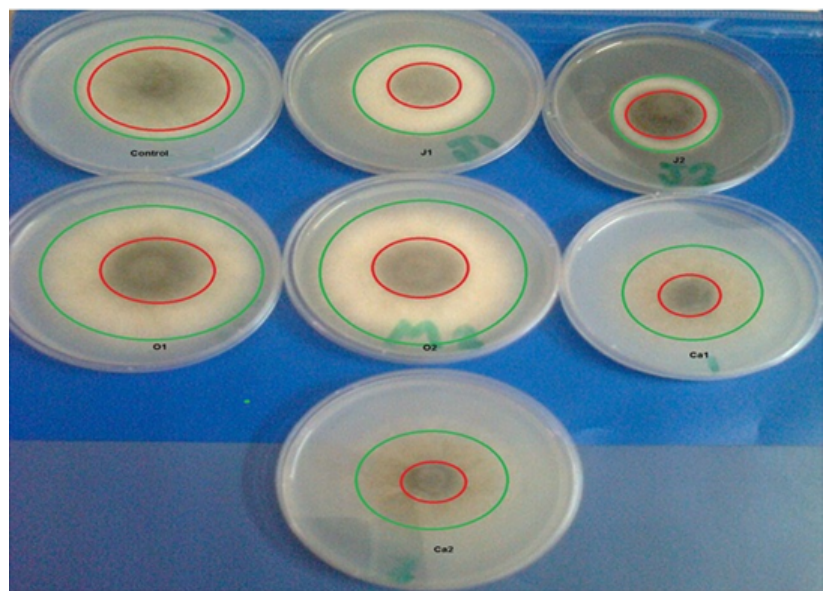

Figure 2: Growth and sporulation of $C$. lunata on treated Czapek-Dox aga medium (J1, J2: 1 and $2 \mathrm{mg} / \mathrm{ml}$ J. procera extract respectively; M1, M2: 1 and $2 \mathrm{mg} / \mathrm{ml}$ A. marina extract respectively; Ca1, Ca2: 5 and $10 \mu \mathrm{g} / \mathrm{ml}$ Carbomar respectively).

\begin{tabular}{|c|c|c|c|c|c|c|c|}
\hline \multirow{2}{*}{$\begin{array}{l}\text { Plant extract } \\
\text { Concentration } \\
(\mathrm{mg} / \mathrm{ml})\end{array}$} & \multicolumn{2}{|c|}{ J. procera } & \multicolumn{2}{|c|}{ A. marina } & \multicolumn{3}{|c|}{ Carbomar } \\
\hline & $\begin{array}{l}\text { Colony radius } \\
\text { (mm) }\end{array}$ & Inhibition (\%) & $\begin{array}{c}\text { Colony radius } \\
(\mathrm{mm})\end{array}$ & Inhibition (\%) & $\begin{array}{l}\text { Concentration } \\
(\mu \mathrm{g} / \mathrm{ml})\end{array}$ & $\begin{array}{c}\text { Colony radius } \\
(\mathrm{mm})\end{array}$ & Inhibition (\%) \\
\hline 0.0 & $5.60 \pm 0.10$ & 0.00 & $5.60 \pm 0.10$ & 0.00 & 0.00 & $5.60 \pm 0.10$ & 0.00 \\
\hline 1.0 & $5.20 \pm 0.10$ & 41.89 & $6.70 \pm 0.12$ & 0.00 & 5.00 & $4.30 \pm 0.02$ & 23.21 \\
\hline 1.5 & $3.90 \pm 0.12$ & 48.64 & $6.70 \pm 0.15$ & 0.00 & 10.0 & $3.20 \pm 0.14$ & 42.85 \\
\hline 2.0 & $3.20 \pm 0.15$ & 59.86 & $5.50 \pm 0.10$ & 8.00 & 25.0 & $1.70 \pm 0.12$ & 69.64 \\
\hline 2.5 & $2.50 \pm 0.12$ & 76.08 & $4.30 \pm 0.12$ & 23.21 & 50.0 & $0.00 \pm 0.00$ & 100 \\
\hline 3.0 & $0.80 \pm 0.06$ & 88.42 & $3.50 \pm 0.10$ & 37.50 & 100 & $0.00 \pm 0.00$ & 100 \\
\hline
\end{tabular}

Table 2: Effect of plant extracts and Carbomar different concentrations on the growth of Curvularia lunata. 
Citation: Abdel Ghany TM, Shater ARM, Negm ME, Al Abboud MA, Elhussieny NI (2015) Efficacy of Botanical Fungicides against Curvularia lunata at Molecular Levels. J Plant Pathol Microb 6: 289. doi:10.4172/2157-7471.1000289

Page 4 of 7

\begin{tabular}{|c|c|c|c|c|c|c|c|}
\hline \multirow[t]{2}{*}{ Secondary metabolite } & \multirow[t]{2}{*}{ Control } & \multicolumn{2}{|c|}{$\begin{array}{l}\text { J. procera extract concentration } \\
\qquad(\mathrm{mg} / \mathrm{ml})\end{array}$} & \multicolumn{2}{|c|}{$\begin{array}{l}\text { A. marina extract concentration } \\
\qquad(\mathrm{mg} / \mathrm{ml})\end{array}$} & \multicolumn{2}{|c|}{$\begin{array}{c}\text { Carbomar Concentration } \\
(\mu \mathrm{g} / \mathrm{ml})\end{array}$} \\
\hline & & 1 & 2 & 1 & 2 & 5 & 25 \\
\hline Cytoskyrins & + & + & + & + & + & + & + \\
\hline Lunatin & + & + & - & + & - & - & - \\
\hline Curvulapyrone & + & - & - & - & - & - & - \\
\hline Curvulalide & + & + & + & + & + & - & - \\
\hline Curvulalic acid & + & + & - & + & + & - & - \\
\hline Radicinin & + & - & - & - & - & - & - \\
\hline Cytochalasin B & + & + & + & - & - & - & - \\
\hline Mycoepoxydiene & + & + & + & - & - & - & - \\
\hline Deacetylmycoepoxydiene & + & + & + & - & - & - & - \\
\hline
\end{tabular}

Table 3: C. Iunata secondary metabolites profiles at different concentration of plant extracts and Carbomar.
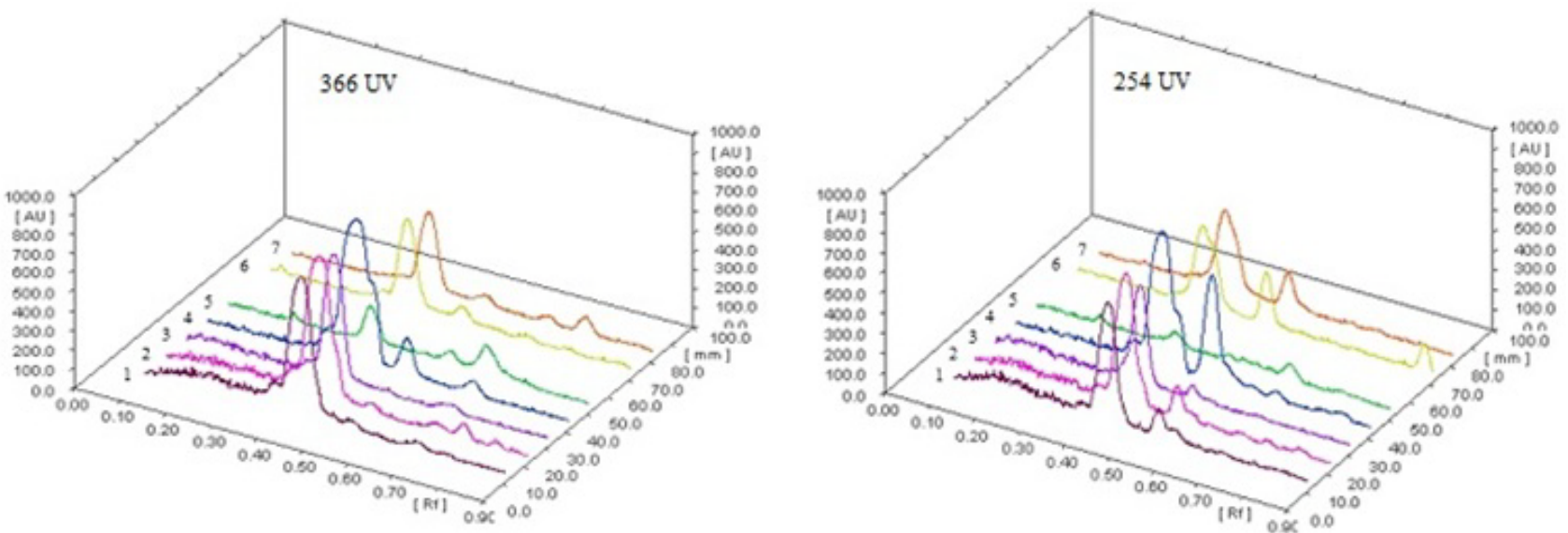

Figure 3: $C$. lunata secondary metabolites profiles at long and short UV wave lengths. (1: control; 2, 3: 1 and $2 \mathrm{mg} / \mathrm{ml} \mathrm{J}$. procera extract respectively; $4,5: 1$ and $2 \mathrm{mg} /$ $\mathrm{ml} \mathrm{A.} \mathrm{marina} \mathrm{extract} \mathrm{respectively;} 6,7: 5,25 \mu \mathrm{g} / \mathrm{ml}$ Carbomar respectively).

\begin{tabular}{|c|c|c|c|c|c|c|c|}
\hline \multirow{2}{*}{$\begin{array}{l}\text { Extract Conc. } \\
\quad(\mathrm{mg} / \mathrm{ml})\end{array}$} & \multicolumn{2}{|c|}{ J. procera extract } & \multicolumn{2}{|c|}{ A. marina extract } & \multicolumn{3}{|c|}{ Carbomar } \\
\hline & DNA & RNA & DNA & RNA & Carbomar $(\mu \mathrm{g} / \mathrm{ml})$ & DNA & RNA \\
\hline 0.0 & $8.75 \pm 0.26$ & $60.50 \pm 0.10$ & $8.75 \pm 0.26$ & $60.50 \pm 0.10$ & 0.00 & $8.75 \pm 0.26$ & $60.50 \pm 0.10$ \\
\hline 1.0 & $10.20 \pm 0.15$ & $65.25 \pm 0.12$ & $9.30 \pm 0.16$ & $75.25 \pm 0.10$ & 5.00 & $4.05 \pm 0.20$ & $45.00 \pm 0.20$ \\
\hline 1.5 & $9.10 \pm 0.25$ & $69.10 \pm 0.20$ & $11.50 \pm 0.20$ & $79.10 \pm 0.09$ & 10.0 & $4.15 \pm 0.20$ & $35.00 \pm 0.10$ \\
\hline 2.0 & $6.15 \pm 0.10$ & $40.22 \pm 0.20$ & $10.00 \pm 0.05$ & $60.22 \pm 0.10$ & 25.0 & $3.05 \pm 0.15$ & $31.00 \pm 0.09$ \\
\hline 2.5 & $6.25 \pm 0.15$ & $40.30 \pm 0.25$ & $7.05 \pm 0.10$ & $50.30 \pm 0.20$ & 50.0 & \multirow{2}{*}{\multicolumn{2}{|c|}{ No fungal growth }} \\
\hline 3.0 & $4.30 \pm 0.20$ & $40.00 \pm 0.20$ & $5.15 \pm 0.26$ & $42.00 \pm 0.08$ & 100 & & \\
\hline
\end{tabular}

Table 4: Effect of different concentrations of J. procera, A. marina extracts and Carbomar on DNA and RNA concentrations (mg/g mats dry weight of mass) of Curvularia lunata.

control. RAPD analysis was extensively used as molecular analysis tool for Curvularia sp. [52-55]. Five 10-mer random primers were tested for RAPD analysis. Four primers (P1, P2, PE7 and PE20) produced considerable bands (Figure 4) while the primer P14 produced no distinct bands. A total of 52 amplified fragments were observed, 33 of them were monomorphic bands while 19 were polymorphic that reflect high degree of polymorphism (36.5\%) among all samples. Comparison of each treatment with the untreated sample (wild type) showed that C. lunata treated with $A$. marina extract showed the highest degree of polymorphism (32\%) among its 50 amplified fragment which recommend that A. marina has high mutagenic efficacy; followed by the carbomar which induced 14 polymorphic band ( $29.2 \%$ polymorphism) from 48 total amplified fragments. These molecular markers can demonstrate similarities and dissimilarities between different isolates of same species even when a morphological description is severely limited. J. procera comes finally as its treated C. lunata samples showed the lowest degree of polymorphism with $19 \%$ polymorphism and 42 amplified fragments (Table 5). Studying the effect of concentration on mutagenic rate in terms of percentage of polymorphism indicated that for J. procera and A. marina it was clear that there is a proportion between the concentration of the treatment and the percentage of polymorphism in the treated C. lunata samples. A. marina extract low concentration result in 35 monomorphic fragments and 8 polymorphic that represent $18.6 \%$ of polymorphism in the treated fungal samples. The high concentration showed higher level of polymorphism with 33 monomorphic fragments and 12 polymorphic fragments $(26.7 \%$ polymorphism). The same phenomena was noticed while studying $J$. procera different concentrations (Table 6).This observation gives good evidence to the ability of these plant extracts and chemical fungicide Carbomar to induce mutation as a result of compromising at least one nucleotide as revealed by the disappearance of many genetic bands and change in restriction endonucleases sites as compared with untreated 
Citation: Abdel Ghany TM, Shater ARM, Negm ME, Al Abboud MA, Elhussieny NI (2015) Efficacy of Botanical Fungicides against Curvularia lunata at Molecular Levels. J Plant Pathol Microb 6: 289. doi:10.4172/2157-7471.1000289
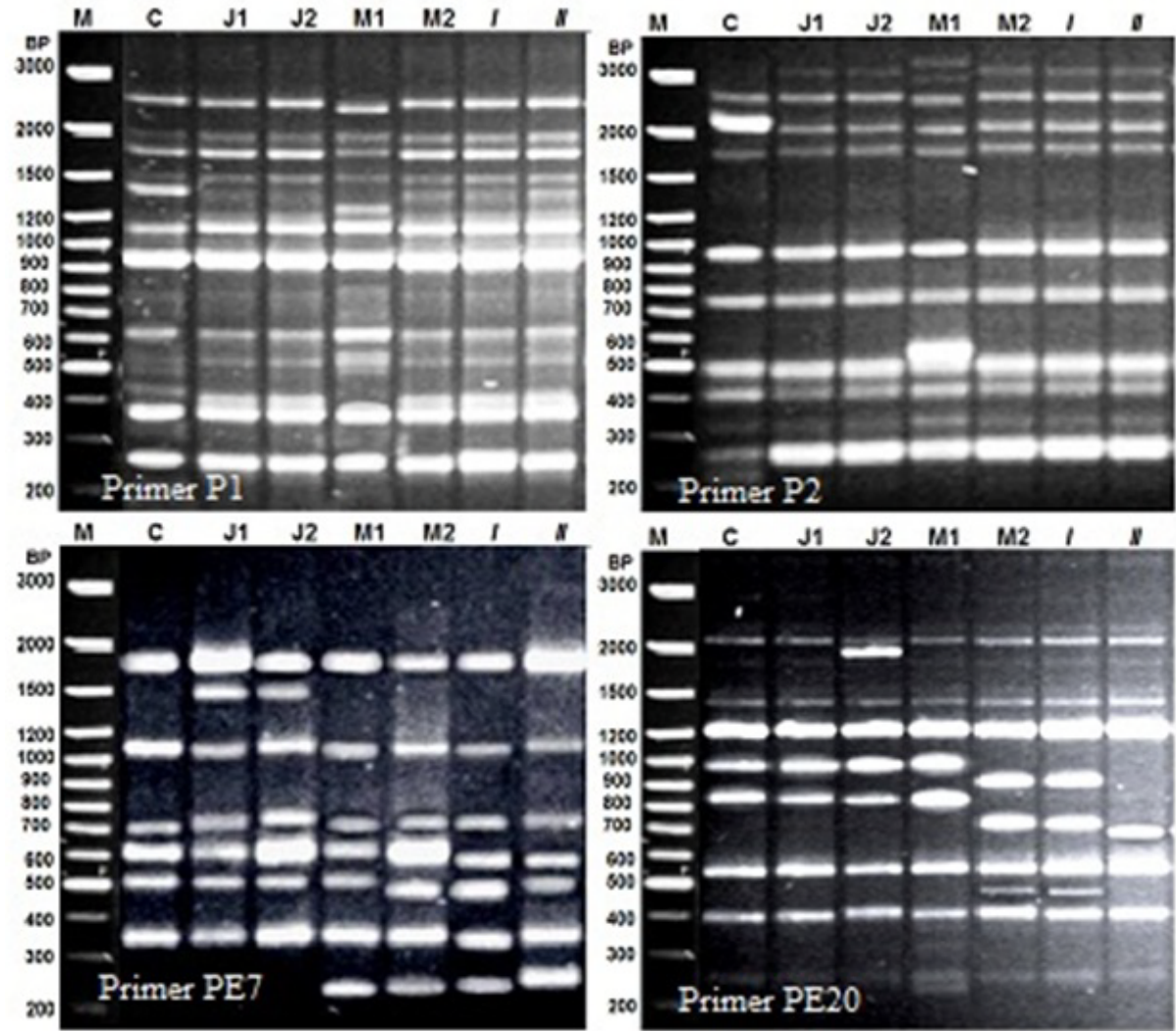

Figure 4: Agarose gels for primers P1, P2, PE7 and PE20 amplification products. (J1, J2: 1 and $1.5 \mathrm{mg} / \mathrm{ml} \mathrm{J}$. procera extract respectively; M1, M2: 1 and 1.5 mg/ml A. marina extract respectively; I, II: 5 and $10 \mu \mathrm{g} / \mathrm{ml}$ Carbomar).

\begin{tabular}{|c|c|c|c|c|c|c|}
\hline \multirow{2}{*}{ Treatment } & \multirow{2}{*}{$\begin{array}{l}\text { Amplification } \\
\text { Products }\end{array}$} & \multicolumn{4}{|c|}{ Ten mer random primers codes } & \multirow{2}{*}{ Total } \\
\hline & & P1 & P2 & PE7 & PE20 & \\
\hline \multirow{3}{*}{ J. procera } & TAF & 14 & 11 & 7 & 10 & 42 \\
\hline & Poly $\%$ & 21.43 & 18.18 & 14.29 & 20.00 & 19.05 \\
\hline & Mono\% & 78.57 & 81.82 & 85.71 & 80.00 & 80.95 \\
\hline \multirow{3}{*}{ A. marina } & TAF & 17 & 12 & 9 & 12 & 50 \\
\hline & Poly\% & 35.29 & 25.00 & 22.22 & 41.67 & 32.00 \\
\hline & Mono\% & 64.71 & 75.00 & 77.78 & 58.33 & 68.00 \\
\hline \multirow{3}{*}{ Carbomar } & TAF & 15 & 11 & 9 & 13 & 48 \\
\hline & Poly\% & 26.67 & 18.18 & 22.22 & 46.15 & 29.17 \\
\hline & Mono\% & 73.33 & 81.82 & 77.78 & 53.85 & 70.83 \\
\hline
\end{tabular}

Table 5: Amplification products polymorphism of treated C. lunata with plant extracts and chemical fungicide carbomar. TAF: total amplified fragments; Poly: Polymorphic fragments; Mono: Monomorphic fragments.

\begin{tabular}{|c|c|c|c|c|c|c|c|c|c|c|c|}
\hline \multirow{2}{*}{ Treatment } & \multirow{2}{*}{$\begin{array}{l}\text { Conc. } \\
\text { (mg/ml) }\end{array}$} & \multicolumn{2}{|c|}{ P1 } & \multicolumn{2}{|c|}{ P2 } & \multicolumn{2}{|c|}{ PE7 } & \multicolumn{2}{|c|}{ PE20 } & \multicolumn{2}{|c|}{ Total } \\
\hline & & TAF & Poly\% & TAF & Poly\% & TAF & Poly\% & TAF & Poly\% & TAF & Poly\% \\
\hline \multirow{2}{*}{ J. procera } & 1.00 & 14 & 21.43 & 11 & 18.18 & 7 & 14.29 & 9 & 0.00 & 41 & 14.63 \\
\hline & 2.00 & 14 & 21.43 & 11 & 18.18 & 7 & 14.29 & 12 & 41.67 & 44 & 25.00 \\
\hline \multirow{2}{*}{ A. marina } & 1.00 & 15 & 26.67 & 12 & 25.00 & 7 & 14.29 & 9 & 0.00 & 43 & 18.60 \\
\hline & 2.00 & 15 & 26.67 & 11 & 18.18 & 7 & 14.29 & 12 & 41.67 & 45 & 26.67 \\
\hline \multirow{2}{*}{ Carbomar } & 0.5 & 15 & 26.67 & 11 & 18.18 & 7 & 14.29 & 13 & 46.15 & 46 & 28.26 \\
\hline & 2.5 & 15 & 26.67 & 11 & 18.18 & 9 & 22.22 & 11 & 36.36 & 46 & 26.09 \\
\hline
\end{tabular}

Table 6: Polymorphism of $C$. lunata treated with plant extracts and chemical fungicide carbomar.

C. lunata. Generally in all cases, polymorphisms were due to the loss and/or gain of amplified bands in the treated samples compared with the control. This result s were agreement with Sameer [56] in their study on the effect of Calotropis procera latex on Aspergillus terreus. Our findings support this claim that DNA polymorphisms detected by
RAPD can be considered as a powerful biomarker assay for detection of the level of DNA damage in various treated C. lunata and to extracts of $J$. procera and A. marina, as suggested by similar results obtained by Hajar and Nehad [57] in their study on the effect of Moringa peregrine extract on bacteria and fungi. 
Citation: Abdel Ghany TM, Shater ARM, Negm ME, Al Abboud MA, Elhussieny NI (2015) Efficacy of Botanical Fungicides against Curvularia lunata at Molecular Levels. J Plant Pathol Microb 6: 289. doi:10.4172/2157-7471.1000289

\section{Acknowledgement}

Thanks to Regional Center of Mycology and Biotechnology, Al Azhar University, Cairo, Egypt for providing laboratory facilities.

\section{References}

1. FAO (2012) Proceedings of the 21st Session of the International Rice Commission in Rome, Italy.

2. Gautam AK, Heena G, Yamini S (2012) Screening of Fungi and Mycotoxins Associated with Stored Rice Grains in Himachal Pradesh. International Journal of Theoretical \& Applied Sciences 4: 128-133.

3. Zeringue HJ, Bhatnagar D (1990) Inhibition of aflatoxin production in Aspergillus flavus infected cotton bolls after treatment with neem (Azadirachta indica) leaf extracts. Journal of American Oil Chemical Society 67: 215-221.

4. Khan SAJ, Khanzada AK, Sultana N, Aslam M (1988) Evaluation of seed health and testing techniques for the assessment of seed borne mycoflora of rice. Pak J Agric Res 9: 502-505

5. Javaid MS, Wahid A, Idrees M, Gill MA, Saleem A (2002) Seed mycoflora studies in rice. Pakistan J Phytopathol 14: 132-134.

6. Nguefack J, Nguikwie SK, Fotio D (2007) Fungicidal potential of essential oils and fractions from Cymbopogon citratus, Ocimum gratissimmum and Thymus vulgaris to control Alternaria padwickii and Bipolaris oryzae, two seed-borne fungi of rice (Oryza sativa L.). J Essential Oil Res 17: 581-587.

7. Barrios LM, Prez IO (2005) Nuevos registros de hongos en semillas de Oryza sativa en Cuba. Manejo Integrado Plagas 75: 64-67.

8. Khasanov BA, Shavarina ZA, Vypritskaya AA (1990) Characteristics of CurvulariaBoedijn fungi and their pathogenicity in cereal crops. Mikol Fitopato 24: $165-173$

9. Khokhar MK, Rawal P, Mathur AC (2011) Effect of fungal metabolites on seed viability and seedling vigour of fenugreek (Trigonella foenum-graecum L). J Mycol Plant Pathol 41: 543-545.

10. Singh SN, Yadav BP, Sinha SK, Ojha KL (1997) Efficacy of plant extract in inhibition of radial growth of Colletotrichum capsici. Journal of Applied biology 51: 180-183.

11. Amadioha AC (2000) Controlling rice blast in vitro and in vivo with extracts of Azadirachta indica. Crop Protection 19: 287-290.

12. Anon (2005) Pest control background. Int J Pest Control 45: 232-233.

13. Taskeen-Un-Nisa, Wani AH, Mohd Yaqub Bhat, Pala SA, Mir RA (2011) In vitro inhibitory effect of fungicides and botanicals on mycelia growth and spore germination of Fusarium oxysporum. Journal of Biopesticides 4: 53-56.

14. Varma J, Dubey NK (1999) Prospectives of botanical and microbial products as pesticides of tomorrow. Curr Sci 76: 172-179.

15. Kuri SK, Islam MR, Mondal U (2010) Effect of aqueous extract of some plants on some stored and field fungi. J Agrofor Environ 4: 37-40.

16. Rahman M (1992) Study on the seed-borne fungi and their control with Botanical and Chemical fungicides on five local Boro varieties of rice. M.S. Thesis, Dept. of Plant Pathology, BAU, Mymensingh. pp: 81-82.

17. Rahman GMM, Islam MR, Wadud MA (1999) Seed treatment with plan extracts and hot water: a potential biophysical method of controlling seed-borne infection of wheat. Bangladesh J. Training and Development. 12: 185-190.

18. Mansur A, Mehbub H, Kamrul H, Chandra KD (2013) Efficacy of Different Plant Extract on Reducing Seed Borne Infection and Increasing Germination of Collected Rice Seed Sample. Universal Journal of Plant Science 1: 66-73.

19. Bobbarala V, Naidu KC (2009) A searches for alternatives to control phytopathogenic fungi Curvularia lunata. Asian Journal of Experimental Sciences 23: 445-450.

20. Akinbode OA (2010) Evaluation of antifungal efficacy of some plant extracts on Curvularia lunata, the causal organism of maize leaf spot. African Journal of Environmental Science and Technology 4: 797-800.

21. Bandaranayake WM (2002) Bioactive compounds and chemical constituents of mangrove plants. Wetlands Ecology and Management 10: 421-52.

22. Namazi R, Zabihollahi R, Behbahani M, Rezaei A (2013) Inhibitory Activity of Avicennia marina, a Medicinal Plant in Persian Folk Medicine, against HIV and HSV. Iran J Pharm Res 12: 435-443.
23. Abeysinghe PD, Wanigatunge RP (2006) Evaluation of antibacterial activity of different mangrove plant extracts. Ruhuna J Science 1: 104-112.

24. Abeysinghe PD, Withanawasam M, Pathirana RN, Abeysinghe S (2002) Preliminary in vitro screening of antibacterial compounds of some mangrove plant extracts for clinical isolates from different sources. Proceeding of the First Science Symposium, University of Ruhuna pp: 22-25.

25. Menghani K, Sharma SK (2012) Antimicrobial activity of Juniperus communis and Solanum xanthocarpum. International J Pharmacetical Sciences and Research 3: 2815-2818.

26. Tumen I, Fred JE, Carol AC, Jeffery AT (2013) Antifungal activity of heartwood extracts from three Juniperus species. Bio Resource 1: 12-20.

27. Abdel Ghany TM (2014) Eco-friendly and Safe Role of Juniperus procera in Controlling of Fungal Growth and Secondary Metabolites. J Plant Pathol Microbiol 5: 231. doi:10.4172/2157-7471.1000231

28. Mariana F, Camelia U (2012) Antimicrobial activity of essential oils against four food-borne fungal strains. UPB Sci Bull Series B 74: 87-98.

29. Ellis MB (1971) Dematiaceous Hyphomycetes. (1stedn) Commonwealth Mycological Institute, Kew, Surrey, UK pp: 608.

30. Grover RK, Moore JD (1962) Toxicometric studies of fungicides against the brown rot organisms Sclerotinia fructivola and S. laxa. Phytopath 52: 876-880.

31. Singh J, Tripatri NN (1999) Inhibition of storage fungi of black gram (Vigna mungo L.) by some essentials. Flavour and Fragrance Journal 14: 1-4.

32. Frisvad JC (1989) The connection between the Penicillia and Aspergilli and mycotoxins with special emphasis on misidentified isolates. Arch Environ Contam Toxicol 18: 452-467.

33. Paterson RRM, Bridge PD (1994) Biochemical techniques for filamentous fungi. CAB International, London, UK.

34. Thrane $U$ (2001) Developments in the taxonomy of Fusarium species based on secondary metabolites. In Fusarium: Paul E. Nelson Memorial Symposium ed. Summerell BA, Leslie JF, Backhouse D, Bryden WL and Burgess, LW. pp: $29-49$

35. Frisvad JC, Andersen B, Thrane U (2008) The use of secondary metabolite profiling in chemotaxonomy of filamentous fungi. Mycol Res 112: 231-240.

36. Altomere C, Petrini O, Logrieco A, Bottalico A (1997) Taxonomic relationships among the toxigenic species Fusarium acuminatum, Fusarium sporotrichioides and Fusarium tricinctum by isozyme analysis and RAPD assay. Canadian Journal of Botany 75: 1674-1684

37. Ajay KG, Heena G, Yamini S (2012) Screening of Fungi and Mycotoxin Associated with Stored Rice Grains in Himachal Pradesh. International Journal of Theoretical \& Applied Sciences 4: 128-133.

38. Devihalli CM, Praveen P, Veena V, Koteshwara AR (2011) Plant extract effect on seed-borne pathogenic fungi from seeds of paddy grown in southern india. J Plant Protection Research 51: 101-106.

39. Lanisnik Rizner T, Wheeler MH (2003) Melanin biosynthesis in the fungus Curvularia lunata (teleomorph: Cochliobolus lunatus). Can J Microbiol 49: 110 119

40. Lanisnik Rizner T, Romih R (2007) Growth media effects on morphology and $17 \beta-H S D$ activity in the fungus Curvularia lunata. Annals of Microbiology 57 $635-643$.

41. Shikha M, Rajashree S, Renu M, Ranjana V (2013) Antifungal Activity of Alcoholic Leaf Extracts of Terminalia catappa and Terminalia Arjuna on Some Pathogenic and Allergenic Fungi. Advances in Life Science and Technology 8: 25-27.

2. Butt AR, Yaseen SI, Javaid A (2011) Seed-borne mycoflora of stored rice grain and its chemical control. The Journal of Animal \& Plant Sciences 21: 193-196.

43. Harris CA, Renfrew MJ, Woolridge MW (2001) Assessing the risks of pesticide residues to consumers: recent and future developments. Food Addit Contam 18: $1124-1129$.

44. Nayak BK, Janaki T, Ganesan T (2014) Antimicrobial activity of Avicennia marina (Forsk) Vierh from Back water area of Puducherry, India. Int J ChemTech Res 6: 4667-4670.

45. Duke N (1990) Phenological trends with latitude in the mangrove tree Avicennia marina. J Ecol 78: 113-33. 
Citation: Abdel Ghany TM, Shater ARM, Negm ME, Al Abboud MA, Elhussieny NI (2015) Efficacy of Botanical Fungicides against Curvularia lunata at Molecular Levels. J Plant Pathol Microb 6: 289. doi:10.4172/2157-7471.1000289

46. Grayer RJ, Harborne JB (1994) A survey of antifungal compounds from higher plants. Phytochemistry 37: 19-42.

47. Al-Rahmah N, Mostafa A, Abdel-Megeed A (2011) Antifungal and antiaflatoxigenic activities of some plant extracts. African J Microbiol Res 5 : $1342-1348$.

48. Trisuwan K, Rukachaisirikul V, Phongpaichit S, Preedanon S, Sakayaroj $J$ (2011) Modiolide and pyrone derivatives from the sea fan-derived fungus Curvularia sp. PSU-F22. Arch Pharm Res 34: 709-714.

49. Visconti A, Sibilia A, (1994) Alternaria toxins. In Miller, J.D and Trenholm H.L(eds). Mycotoxins ingrains: Compounds other than aflatoxin. Eagan Press. St. Paul, Minnesota. USA. pp: 315-338.

50. Cole RJ, Schweikert MA (2003) Handbook of secondary fungal metabolites. Academic Press, New York.

51. Al-Qurainy F, Abdel-Megeed A (2009) Phytoremediation and detoxification of some pesticides residues in Riyadh area. World Applied Sciences Journal 6: 987-998

52. Iftikhar A, Shazia I, John C (2006) Genetic variability and aggressiveness in curvularia lunata associated with rice-wheat cropping areas of Pakistan. Pak J Bot 38: 475-485.

53. Shan FY, Wei SW, Jie LY, Cheng ZJ, Gao DJ (2008) Parasitic fitness and RAPD analysis of Curvularia species on corn. Journal of Agricultural University of Hebei 31: 37-41.

54. Hong-hai Y (2009) Study on RAPD for Physiological Differentiation of Curvularia lunata in Maize. Acta Agriculturae Boreali-Sinica 24: 258-261.

55. Alex D, Li D, Calderone R, Peters SM (2013) Identification of Curvularia lunata by polymerase chain reaction in a case of fungal endophthalmitis. Med Mycol Case Rep 2: 137-140.

56. Qari SH (2008) Molecular and biochemical evaluation of genetic effect of Calotropis procera (Ait.) latex on Aspergillus terreus (Thom). Indian J Exp Bio 46: $725-730$

57. Hajar AS, Nehad MG (2014) Antimicrobial activities and evaluation of genetic effects ofMoringa peregrina (forsk) fiori using molecular techniques. International Journal of Plant, Animal and Environmental Sciences 4: 65-72. 